\title{
Investigation of the Environmental Problems Attitudes of the Undergraduate History Student
}

\author{
Volkan DURAN, Cengiz ATLI, Zeynep Müjde SAKAR, Kenan BAŞ \\ Assistant Professor. Iğdır University Faculty of Science / Letters Department of Psychology Ağrı - Turkey, \\ Associate, Iğdır University Faculty of Science / Letters Department of History Ağrı - Turkey, \\ Associate, Harran University Faculty of Economics and Administrative Sciences, Department of Economics, Ağrı - Turkey, \\ Assistant Professor, Ağrı İbrahim Çeçen University, Patnos School of Social Services, Department of Social Services, Ağrı - Turkey,
}

\begin{abstract}
This research aims to investigate the students' affective domain and attitudes and their perceptions about environmental problems by providing strength formula and significance formula. This research is based on a mixed research design where both qualitative and quantitative data were used. The sample of this research consists of 236 students using the convenience sampling method at Ibrahim Chechen University, Iğdır University, Gaziosmanpaşa University, and Kafkas University in Turkey. The measurement tool of this study is 45-item having five dimensions Environmental Problems Attitude Scale which provided validity and reliability was developed as a result of the study conducted by Güven (2013). In the analysis of the quantitative data, the strength and significance of strength values show that all dimensions of the affective domain are too weak according to the equations proposed there. Therefore, we can conclude that students' inconsistent and low-level environmental problems attitudes seem to show that they are actually at receiving/attending level. When the sentiment analysis was conducted on the qualitative data, we got a neutral tone regarding the formation of environmental understanding in the Ottoman Empire and the Turkish Republic.
\end{abstract}

Keywords: Environmental problems attitude, affective domain, sentiment analysis, neural network analysis, path analysis

\section{INTRODUCTION}

Growing data advocates the idea that people are intrinsically emotional beings and emotion and affective development have an important effect on human development and behavior in many respects (Brett, Smith, Price, \& Huitt, 2003). Pure data and information are not enough for us to understand human cognitive sides. Knowledge, wisdom, and ideas are also not only related to data and information that they are derived from but also are associated with emotions developed in parallel to the cognitive learning process. We don't make decisions based on information, but we also look at the emotion-related to it. Our motivations and drives are also mainly developed from those emotions. For instance, when a good friend of someone asks him/her why he is late for work, this can be interpreted as a worry about the presence of him/her by the person. However, when the same question is asked by a very old opponent in the job, this is probably interpreted as digging a pit for the person mentioned in the first case. Just as in this example, information is mostly attached to emotions which are mainly characterized by the affective domain. Although the sometimes affective domain is considered to be very opposed to the cognitive domain and is seen as more chaotic than cognitive elements, it also has some levels and logical structure within itself. Awareness of a certain problem is not at the same level as committing to seeking an active solution for it according to the affective domain taxonomy of Bloom, et al. (1956) where there are five levels as Receiving/attending, Responding, Valuing, Organisation, Internalisation (Figure 1).

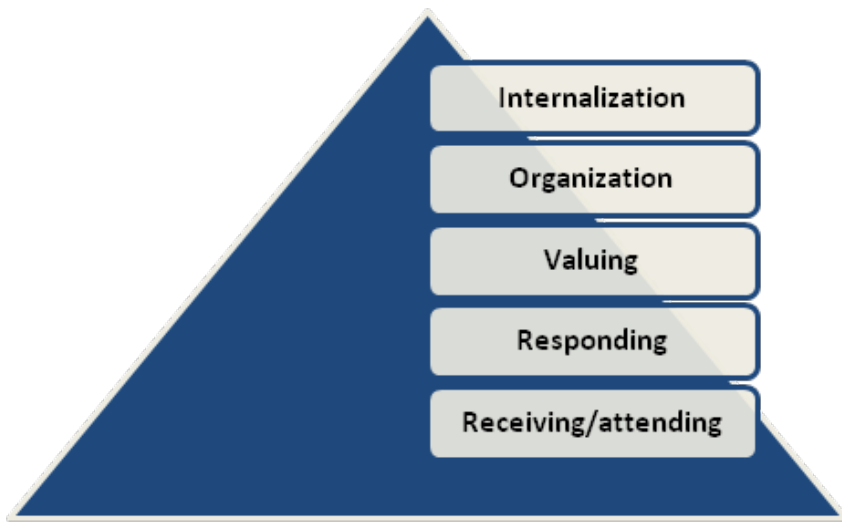

Figure 1: The affective domain taxonomy of Bloom, et al. (1956)

Corresponding Author e-mail: volkan.duran8 @ igdir.edu.tr https://orcid.org/0000-0002-5244-7790

How to cite this article: DURAN V, ATLI C, BAŞ K, (2021). Investigation of The Environmental Problems Attitudes of the Undergraduate History Student. Pegem Journal of Education and Instruction, Vol. 11, No. 4, 2021, 337-352

Source of support: Nil

Conflict of interest: None.

DOI: $10.47750 /$ pegegog.11.04.33

Received: 07.06.2021

Accepted: 18.09.2021 Publication: 01.10.2021 
Nevertheless, it should be underlined that research on the affective domain is less compared to the cognitive domain in the literature. The lack of research in the affective domain seems to be largely based on the assumption that it is difficult to distinguish the affective domain from the cognitive and psychomotor field, that it would be difficult to settle on and concretize affecting objectives, that the instruction of affective objectives will take a long time, and that they will be difficult to assess (Bacanll, 1999). In this respect, it is thought that this study contributes to the literature in terms of examining students' environmental problems attitudes in the context of the affective domain. In addition to neglecting effective goals, Tekin (2003: 209) emphasized that educators do not underline the realization and measurement of effective learning. This study is also important in terms of the evaluation of affective domains since it brings different statistical models and mathematical analysis proposed for the evaluation of effective features.

Environmental awareness is important for historians because historians having environmental awareness are more prone to reading historical events in the context of environmental issues and, hence, they more contribute to the field in this respect. Additionally, environmental problems are directly related to history because it covers many topics, from the danger of extinction of cultural heritage to how people dealt with environmental issues in the past. Jared Diamond's book of Collapse (2005), discussing why well-run societies fail and how the actions of people who harvest trees, farm, hunt, or fish can harm the environment so it returns them as well in the end, can be regarded as a good example showing how environmental awareness produce novel works in the context of history and environmental problems. Affective dimensions and attitudes toward environmental problems are also important for teacher training given that the positive environmental attitudes of the teacher candidates would ensure the positive development of the environmental attitudes of the students being taught by them in the future. Although our sample is not from history teachers, it should be noted that most of the students in history departments prefer to be a teacher after their graduation by taking additional pedagogical courses. In this respect, it is of great importance that the attitude of teacher candidates who are trained in environmental education and environmental awareness regarding environmental problems should be assessed and that the candidates should take the necessary steps to eliminate and avoid environmental problems by taking measures that are in line with the results (Güven, 2013).

The affective domain of learning in recent studies seems to be gaining importance. Also, when considering that emotions are more likely to influence attitudes and beliefs, given how essential the function they are in the life of an individual ((Broekens, Kosters \& Verbeek, 2007; Lopes, Brackett, Nezlek, Schütz, Sellin, \& Savery positivey, 2004) it is important to examine the attitude of the environmental problem of the students since it gives the clue of their rationale behind their emotions and provides us with an understanding how we motivate them coherently and educationally. Therefore, this research aims to investigate the students' affective domain and attitudes and their perceptions about environmental problems. This can be achieved by the following research questions:

1. Are there any significant differences in students' Environmental Problems Attitude in terms of demographic variables?

1a) Are there any significant differences in students' Environmental Problems Attitude in terms of gender?

1b) Are there any significant differences in students Environmental Problems Attitude in terms of their grades?

1c) Are there any significant differences in students' Environmental Problems Attitude in terms of whether they like their departments or not?

1d) Are there any significant differences in students' Environmental Problems Attitude in terms of graduation?

1e) Are there any significant differences between students' Environmental Problems Attitude in terms of their location where they live?

1f) Which demographic variable is the most important factor for students' Environmental Problems Attitudes?

2. Is there any significant correlation between the subdimensions of the Environmental Problems Attitude of the students?

3. Are there any significant causal and predictive connections among the sub-dimensions of the Environmental Problems Attitude of the students?

4. What are the results of sentiment analysis regarding the students' opinions on the environmental understanding in the Ottoman Empire and the modern Turkish Republic?

\section{Method}

\section{Research Design}

This research was based on a mixed research design where both qualitative and quantitative data were used. The details about the research design is as in the following:

\section{Study Group}

The study group of this study consisted of history students at Ibrahim Chechen University, Iğdır University, Gaziosmanpaşa University, and Kafkas University in Turkey. Since we focused only on the students in history departments, these four universities were selected using convenience sampling method because they were in the accessible part of the researchers for conducting this research in terms of both ethical 
permissions as well as its reachability in terms of time and funding.

It should be noted that many students are living in different regions in these universities, so it is concluded these four universities can be taken as the population of this research. The sample of this research consists of 236 students using the convenience sampling method, which is a type of nonprobability sampling method where the sample is taken from a group of people easy to contact or to reach in terms of time, money (Büyüköztürk, Çakmak, Akgün, Karadeniz ve Demirel, 2011: 84). The characteristics of the sample in terms of grade and gender as given in Table 1. It is observed that most of the students are in 2'th grade and there are fewer students in prep class because most students in history departments don't prefer prep classes (Table 1).

The characteristics of the sample in terms of the location of students where they live and gender as given in Table 2 . According to this most students are living in the Eastern Anatolia region.

The quantitative part of this research is based on a descriptive study carried out using a cross-sectional survey model. According to Karasar (2003), survey models are a research approach that aims to describe a past or present situation as it is. In the cross-sectional screening model, the aim is to define the condition of the screened case at any time (Özdemir, 2015). A random sampling of the variables involves completing a questionnaire centering on the variables of the topic the researcher is interested in. Additionally, we use the formula of the number sample size suggested by (Tabachnick and Fidell, 2007) given as follows:

$$
\mathrm{N}>50+8 m
$$

$\mathrm{N}$ : Number of participants m: number of independent variables where $m=11$ (5 independent variables from the scale, 6 variables from demographic variables)

$\mathrm{N}>138$ where the target sample size for this study is 236 which meets the requirement.

The measurement tool for this study is 45-item having five dimensions. The Environmental Problems Attitude Scale which provided validity and reliability was developed as a result of the study conducted by Güven (2013). In the analysis of the quantitative data, non-parametric tests were used, such as the Mann-Whitney U test, Kruskal Wallis Test, Spearman

Table 1: The characteristics of the sample in terms of grade and gender

\begin{tabular}{|c|c|c|c|c|c|c|c|}
\hline \multirow[b]{2}{*}{ Prep } & & \multicolumn{5}{|c|}{ Class } & \multirow[b]{2}{*}{ Total } \\
\hline & & 1.grade & 2.grade & 3 grade & 4 grade & & \\
\hline \multirow[t]{2}{*}{ Gender } & Female & 1 & 36 & 62 & 18 & 33 & 150 \\
\hline & Male & 2 & 23 & 25 & 13 & 23 & 86 \\
\hline Total & & 3 & 59 & 87 & 31 & 56 & 236 \\
\hline
\end{tabular}

Table 2: The characteristics of the sample in terms of the location of students where they live and gender

\begin{tabular}{|c|c|c|c|c|c|c|c|c|c|}
\hline \multirow{2}{*}{\multicolumn{2}{|c|}{ Southeastern Anatolia }} & \multicolumn{7}{|c|}{ Region } & \multirow[b]{2}{*}{ Tota } \\
\hline & & \multirow{2}{*}{$\begin{array}{l}\begin{array}{l}\text { Eastern } \\
\text { Anatolia }\end{array} \\
35\end{array}$} & \multirow{2}{*}{$\begin{array}{l}\text { Central } \\
\text { Anatolia } \\
82\end{array}$} & \multirow{2}{*}{$\begin{array}{l}\text { Mediterranean } \\
4\end{array}$} & \multirow{2}{*}{$\frac{\text { Black Sea }}{7}$} & \multirow{2}{*}{$\frac{\text { Aegean }}{4}$} & \multicolumn{2}{|c|}{ Marmara } & \\
\hline Gender & Female & & & & & & 8 & 10 & 150 \\
\hline & Male & 15 & 43 & 3 & 13 & 5 & 3 & 4 & 86 \\
\hline Total & & 50 & 125 & 7 & 20 & 9 & 11 & 14 & 236 \\
\hline
\end{tabular}
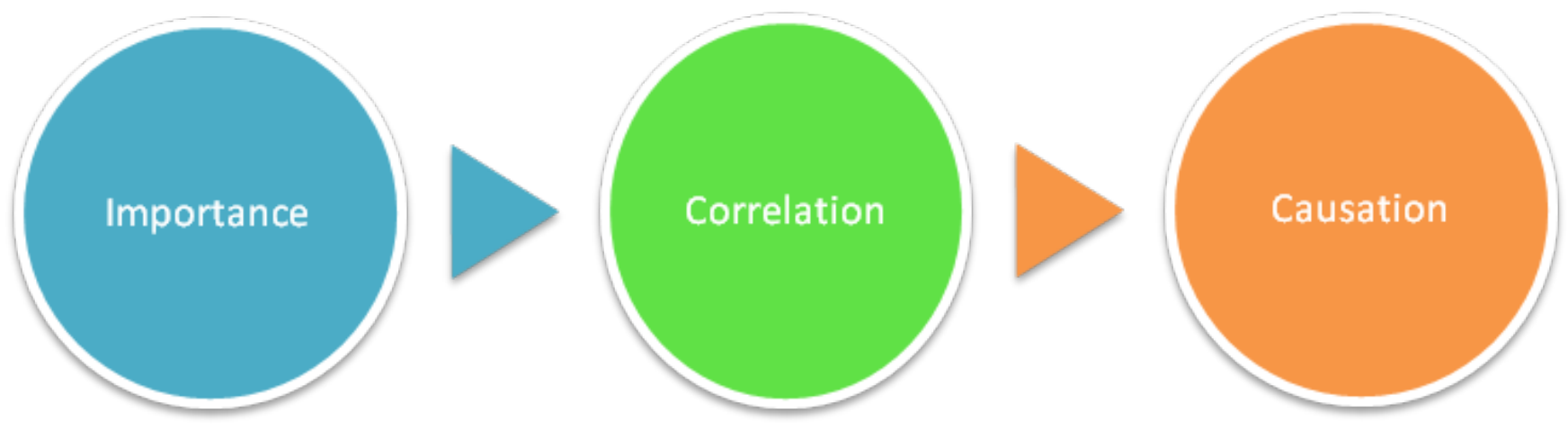

Figure 2. In the analysis, initially, normalized importance values are explored, before the correlation values, and lastly, the path analysis explores the causal connections among the dimensions. 
correlational analysis in SPSS. Furthermore, artificial neural network analysis for the importance of the variables as well as the path analysis in the AMOS program was used.

\section{Data Collection Tools}

The measurement tool of this study is 45 -item having five dimensions Environmental Problems Attitude Scale which provided validity and reliability was developed as a result of the study conducted by Güven (2013).

\section{Data Analysis}

For the analysis of the qualitative data, we use sentiment analysis from the website [1] given in the footnote. The sentiment analysis was done to two open-ended questions given as "What are your thoughts on the importance of foundations and associations in the formation of environmental understanding in the Ottoman Empire?" and "2-What are your thoughts on the importance of education in the development of environmental awareness in Turkey?" to investigate the sentimental neutral tone according to seoscout online sentiment analysis. Actually, in these questions, we don't want to get their information about the subject but their emotions regarding the concept. Kruskal Wallis Test results for the mean rank values of the number of words in terms of emotions were analyzed regarding the formation of environmental understanding. The percentage of the words in terms of emotions given the frequency tables were compared finally at the end.

\section{FINDINGS}

First of all, non-parametric tests are used for the analysis of the data since the data was not normally distributed in terms of Kolmogorov-Smirnov and Shapiro-Wilk tests.

\subsection{Are there any significant differences in students' Environmental Problems Attitude in terms of demographic variables?}

\section{1.a. Are there any significant differences in students' Environmental Problems Attitude in terms of gender?}

Mann-Whitney $U$ test results show that there is a significant difference between students' environmental problems attitudes in terms of gender for responding dimension. In other dimensions, there is no significant difference in terms of gender. Mean rank results show that females have a higher mean rank than males $(129,57>99,19)$ (Table 3).

Table 3: Mann-Whitney U test results in terms of gender

\begin{tabular}{llllll}
\hline & \multicolumn{5}{c}{ Test Statisticsa } \\
\hline & Internalizing & Organizing & Valuing & Responding & Receiving \\
\hline Mann-Whitney U & 6101,000 & 5539,500 & 5766,000 & 4789,500 & 5882,500 \\
Wilcoxon W & 9842,000 & 16864,500 & 9507,000 & 8530,500 & 9623,500 \\
Z &,- 703 & $-1,815$ & $-1,382$ & $-3,320$ & $-1,165$ \\
Asymp. Sig. (2-tailed) &, 482 &, 070 &, 167 &, 001 &, 244 \\
\hline
\end{tabular}

a. Grouping Variable: gender

Table 4: Kruskal Wallis Test results in terms of their grades

\begin{tabular}{llllll}
\hline & \multicolumn{5}{c}{ Test Statisticsa,b } \\
\hline & İnternalizing & Organizing & Valuing & Responding & Receiving \\
\hline Chi-Square & 3,314 & 2,711 & 3,960 & 6,072 & 4,873 \\
Df & 4 & 4 & 4 & 4 & 4 \\
Asymp. Sig. &, 507 &, 607 &, 411 &, 194 &, 301 \\
\hline
\end{tabular}

a. Kruskal Wallis Test

b. Grouping Variable: class

Table 5: Kruskal Wallis Test results in terms of whether they like their departments or not

\begin{tabular}{lllllll}
\hline & \multicolumn{5}{c}{ Test Statisticsa,b } \\
\hline Chi-Square & İnternalizing & Organizing & Valuing & Responding & Receiving \\
Df & 6,379 & 4,615 & 2,538 & 4,478 &, 422 \\
Asymp. Sig. & 3 & 3 & 3 & 3 & 3 &, 936 \\
\hline
\end{tabular}

a. Kruskal Wallis Test

b. Grouping Variable: like department 


\section{1.b. Are there any significant differences in student's Environmental Problems Attitude in terms of their grades?}

The Kruskal Wallis test shows that there is no significant difference between students' environmental problems attitudes in terms of their grades (Table 4).

\section{1.c. Are there any significant differences in students' Environmental Problems Attitude in terms of whether they like their departments or not?}

Kruskal Wallis Test shows that there is no significant difference for student's environmental problems attitude in terms of whether they like their departments or not (Table 5).

\section{1.d. Are there any significant differences in students' Environmental Problems Attitude in terms of graduation?}

The Kruskal Wallis Test shows that there is no significant difference between students' environmental problems attitudes in terms of graduation except for the receiving dimension (Table 6).

Mean ranks for receiving dimension show that the lowest mean rank belongs to science high school and the highest one belongs to vocational high school (Table 7).

\section{1.e Are there any significant differences in students' Environmental Problems Attitude in terms of their location where they live?}

The Kruskal Wallis Test shows that there is no significant difference between students' environmental problems attitudes in terms of their location where they live (Table 8).

\section{1.f. Neural network analysis for the importance of} demographic variables for students' Environmental Problems Attitude

A Model summary for the neural network analysis for the importance of demographic variables for students' environmental problems attitude was given in Table 9. According to Table 9, the sum of squares error for training is 11,356 and the sum of squares error for testing is 4,844 .

The model structure of the neural network analysis was given in Figure 2.

Independent variable importance analysis shows that the most important factor for the demographic variables for students' environmental problems is gender and the second important factor is their attitude toward their departments (Table 10).

\subsection{Spearman correlational analysis for the sub- dimensions of the Environmental Problems Attitude of the students}

When the mean values of the students' answers were investigated, it can be proposed that their level could be associated with responding level since they have the highest scores compared to others (Figure 3 ).

Spearman's correlational analysis of the sub-dimensions of the Environmental Problems Attitude was given in Table 11. It is seen that most of the sub-dimensions have a weak correlation with each other.

Table 6: Kruskal Wallis Test results in terms of responding dimension

\begin{tabular}{llllll}
\hline & \multicolumn{5}{c}{ Test Statisticsa,b } \\
\hline Chi-Square & İnternalizing & Organizing & Valuing & Responding & Receiving \\
Df & 3,017 & 12,016 & 4,372 & 5,519 & 14,041 \\
Asymp. Sig. & 6 & 6 & 6 & 6 & 6 \\
\hline
\end{tabular}

a. Kruskal Wallis Test

b. Grouping Variable: highschool

Table 7.: Mean ranks for receiving dimension

\begin{tabular}{llll}
\hline Ranks & & & \\
\hline Receiving & Highschool & $N$ & Mean Rank \\
& religious vocational high school & 31 & 104,89 \\
& regular high school & 22 & 110,27 \\
& anatolian high school & 107 & 115,39 \\
& vocational high school & 60 & 132,85 \\
& open education high school & 4 & 128,50 \\
& science high school & 6 & 63,75 \\
& social sciences high school & 6 & 179,00 \\
& Total & 236 & \\
\hline
\end{tabular}


Table 8: Kruskal Wallis Test results in terms of their location where they live

\begin{tabular}{lllllll}
\hline Test Statisticsa, $b$ & \multicolumn{7}{l}{} & & \\
\hline & Characterizing & Organizing & Valuing & Responding & Receiving \\
\hline Chi-Square & 5,086 & 6,046 & 10,805 & 4,667 & 4,988 \\
Df & 6 & 6 & 6 & 6 & 6 \\
Asymp. Sig. &, 533 &, 418 &, 095 &, 587 &, 545 \\
\hline
\end{tabular}

a. Kruskal Wallis Test

b. Grouping Variable: location

Table 9: Model summary for the neural network analysis for the importance of demographic variables for student's environmental problems attitude

\begin{tabular}{|c|c|c|c|}
\hline \multicolumn{4}{|c|}{ Model Summary } \\
\hline \multirow[t]{9}{*}{ Training } & Sum of Squares Error & & 11,356 \\
\hline & Average Overall Relative Error & & 974 \\
\hline & Relative Error for Scale Dependents & Characterizing & 968 \\
\hline & & Organizing & ,995 \\
\hline & & Valuing & ,983 \\
\hline & & Responding & 920 \\
\hline & & Receiving & ,999 \\
\hline & Stopping Rule Used & & $\begin{array}{l}1 \text { consecutive step }(\mathrm{s}) \text { with no decrease } \\
\text { in errora }\end{array}$ \\
\hline & Training Time & & 0:00:00,06 \\
\hline \multirow[t]{7}{*}{ Testing } & Sum of Squares Error & & 4,844 \\
\hline & Average Overall Relative Error & & ,996 \\
\hline & Relative Error for Scale Dependents & Characterizing & ,987 \\
\hline & & Organizing & 1,028 \\
\hline & & Valuing & 1,007 \\
\hline & & Responding & ,935 \\
\hline & & Receiving & 991 \\
\hline
\end{tabular}

a. Error computations are based on the testing sample.

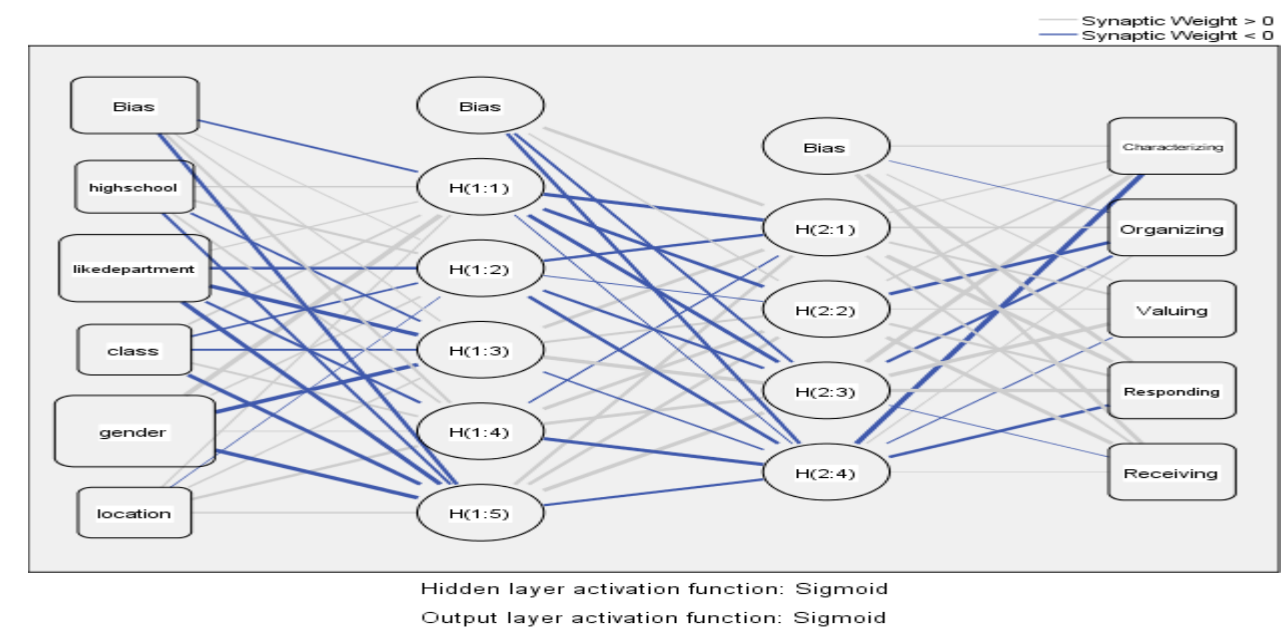

Figure 2: Model structure of the neural network analysis

To better grasp the underlying structure of correlational analysis and to develop a model for it, the researchers created a graph that depicted the relationships and weights between the variables. It was discovered that the responding dimension has the most relationships because it has four connections, followed by the valuing, Characterizing, and receiving dimensions, each 
Table 10: Independent variable importance analysis results for the demographic variables for student's environmental problems attitude

\begin{tabular}{lll}
\hline \multicolumn{2}{l}{ Independent Variable Importance } & \\
\hline & Importance & $\begin{array}{l}\text { Normalized } \\
\text { Importance }\end{array}$ \\
\hline Graduation &, 131 & $37,0 \%$ \\
Likedepartment &, 304 & $86,1 \%$ \\
Class &, 106 & $30,1 \%$ \\
Gender &, 353 & $100,0 \%$ \\
Location &, 106 & $30,0 \%$ \\
\hline
\end{tabular}

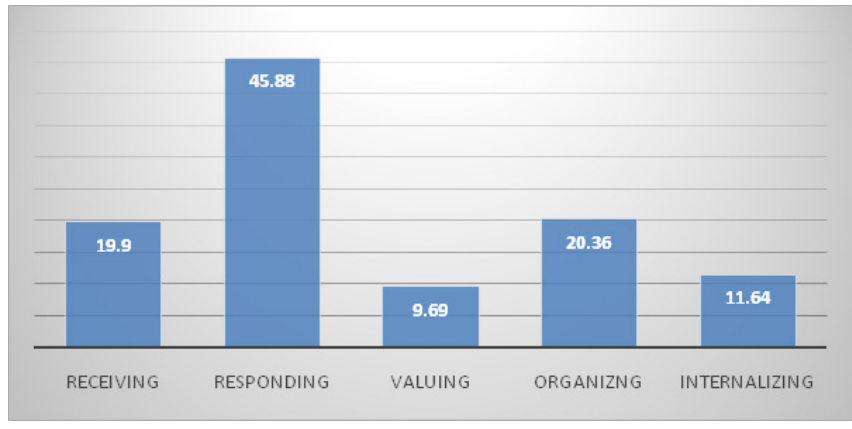

Figure 3: Mean values of the sub-dimensions.

Table 11: Correlation table

\begin{tabular}{|c|c|c|c|c|c|c|c|}
\hline \multicolumn{8}{|c|}{ Correlations } \\
\hline & & & Characterizing & Organizing & Valuing & Responding & Receiving \\
\hline \multirow[t]{15}{*}{ Spearman's rho } & Characterizing & $\begin{array}{l}\text { Correlation } \\
\text { Coefficient }\end{array}$ & 1,000 &, 032 &, $488^{\star *}$ &, $347^{\star *}$ &, $170^{\star \star}$ \\
\hline & & Sig. (2-tailed) & . & ,629 &, 000 &, 000 & ,009 \\
\hline & & $\mathrm{N}$ & 236 & 236 & 236 & 236 & 236 \\
\hline & Organizing & $\begin{array}{l}\text { Correlation } \\
\text { Coefficient }\end{array}$ & ,032 & 1,000 &, $158^{*}$ &,$- 139^{*}$ &,- 084 \\
\hline & & Sig. (2-tailed) & ,629 & . &, 015 &, 033 & ,198 \\
\hline & & $\mathrm{N}$ & 236 & 236 & 236 & 236 & 236 \\
\hline & Valuing & $\begin{array}{l}\text { Correlation } \\
\text { Coefficient }\end{array}$ &, $488^{\star *}$ &, $158^{*}$ & 1,000 &, $274^{\star *}$ &, 037 \\
\hline & & Sig. (2-tailed) & ,000 & ,015 & . & ,000 &, 572 \\
\hline & & $\mathrm{N}$ & 236 & 236 & 236 & 236 & 236 \\
\hline & Responding & $\begin{array}{l}\text { Correlation } \\
\text { Coefficient }\end{array}$ &, $347^{\star *}$ &,$- 139^{*}$ &, $274^{* *}$ & 1,000 &, $178^{\star *}$ \\
\hline & & Sig. (2-tailed) & ,000 &, 033 &, 000 & . &, 006 \\
\hline & & $\mathrm{N}$ & 236 & 236 & 236 & 236 & 236 \\
\hline & Receiving & $\begin{array}{l}\text { Correlation } \\
\text { Coefficient }\end{array}$ &, $170^{* *}$ &,- 084 &, 037 &, $178^{\star *}$ & 1,000 \\
\hline & & Sig. (2-tailed) & ,009 & ,198 &, 572 & ,006 & . \\
\hline & & $\mathrm{N}$ & 236 & 236 & 236 & 236 & 236 \\
\hline
\end{tabular}

**. Correlation is significant at the 0.01 level (2-tailed).

*. Correlation is significant at the 0.05 level (2-tailed).

of which has three connections, and the organizing dimension, which has two connections. First and foremost, the number of connections or correlations is insufficient for determining the structure underlying the correlational analysis since certain dimensions may have more connections but less correlation, while others may have fewer connections but more correlation, and so forth. It was thus necessary to evaluate the strength of these values using the interpretation of the correlation coefficient's range $(r)$, and the categorization was as follows:

- Very weak correlation or no correlation if $r<0.2$

- Weak correlation between $0.2 \leq \mathrm{r}<0.4$

- A moderate correlation between $0.4 \leq \mathrm{r}<0.6$

- The high correlation between $0.6 \leq \mathrm{r}<0.8$
- If $0.8 \geq \mathrm{r}$, it is interpreted that there is a very high correlation.

In order to make those ranges more concrete, we give numbers to each range, similar to how 5-point Likert type scales are used. Extremely weak correlation receives one point, weak correlation receives two points, moderate correlation receives three points, strong correlation receives four points, and very high correlation receives five points, according to this formula. It is understood that if the correlation is positive, each range receives a positive point, and if the correlation is negative, each range receives a negative point. The following formula was used to determine the strength of the link as a result of this: 
$\mathrm{S}_{(\text {sub-dimension-i) }}=\sum_{(\mathrm{i}=0)}^{\mathrm{n}} \mathrm{c}_{\mathrm{i}} \times \mathrm{p}_{\mathrm{i}}$

eqn 1

Where S stands for strength of the connection, ci connection number, pi refers to the connection point. To understand how the formula works, let us look at the strength of the connection of the responding dimension. There are 2 positive weak connections and there are 2 very weak connections. One is a negative correlation so that it takes- 1 , hence our formula for the sub-dimension of responding can be given like this:

n

$S_{\text {responding }}=\sum_{i=0}^{n} c_{i} \times p_{i} 1 \times 1+1 \times 1=2$

Therefore we find $\mathrm{S}_{\text {responding }}=4, \mathrm{~S}_{\text {valuing }}=6, \mathrm{~S}_{\text {resceving }}=$ $2, \mathrm{~S}_{\text {characterizing }}=6, \mathrm{~S}_{\text {organizing }}=0$

$S_{\text {responding }}=\sum_{i=0}^{n} c_{i} \times p_{i=}$.

$$
1 * 2+1 *(-1)+1 * 2+1 *(1)=4
$$

$S_{\text {valuing }}=\sum_{i=0}^{n} c_{i} \times p_{i=1} * 3+1 * 1+1 * 2=5$

$S_{\text {characterizing }}=\sum_{i=0}^{n} c_{i} \times p_{i=1} * 3+1 * 2+1 * 1=6$

$S_{\text {organizing }}=\sum_{i=0}^{n} c_{i} \times p_{i=1} *_{-} 1+1 * 1=0$

It can be seen that although responding has more connections, Characterizing, valuing dimensions has more strength than responding. Therefore, we try to order these concepts in the pyramid in terms of their strength values (Figure 4).
The neural network analysis was used to reveal the importance level of each sub-dimensions based on a model that has two hidden layers where the hidden layer activation function is hyperbolic tangent and the output layer activation function is the sigmoid function by using an optimization method as gradient descent. The results given are in the table 12 below.

We can modify the strength of the connection was calculated by the formula given equation 2 where $i_{k}$ stands for the point from importance level based on the following values:

If $0 \leq i_{k}<20$, then $i_{k}=1$

If $20 \leq i_{k}<40$, then $i_{k}=2$

If $40 \leq i_{k}<60$, then $i_{k}=3$

If $60 \leq i_{k}<80$, then $i_{k}=4$

If $80 \leq i_{k} \leq 100$, then $i_{k}=5$

We can modify equation 1 by adding the importance level value

$$
\mathrm{L}_{\mathrm{s}}=\mathrm{c}_{\mathrm{i}} \times \mathrm{p}_{\mathrm{j}} \times \mathrm{i}_{\mathrm{k}}
$$

Eqn 2

Therefore the new modified formula for the strength of the nodes can be represented by each node defined as a subdimension:

$$
S_{\text {sub-dimension }-i}=\sum L_{s}=\sum_{i=0, j=0, k=0}^{n} c_{i} \times p_{j} \times i_{k}
$$

Eqn 3
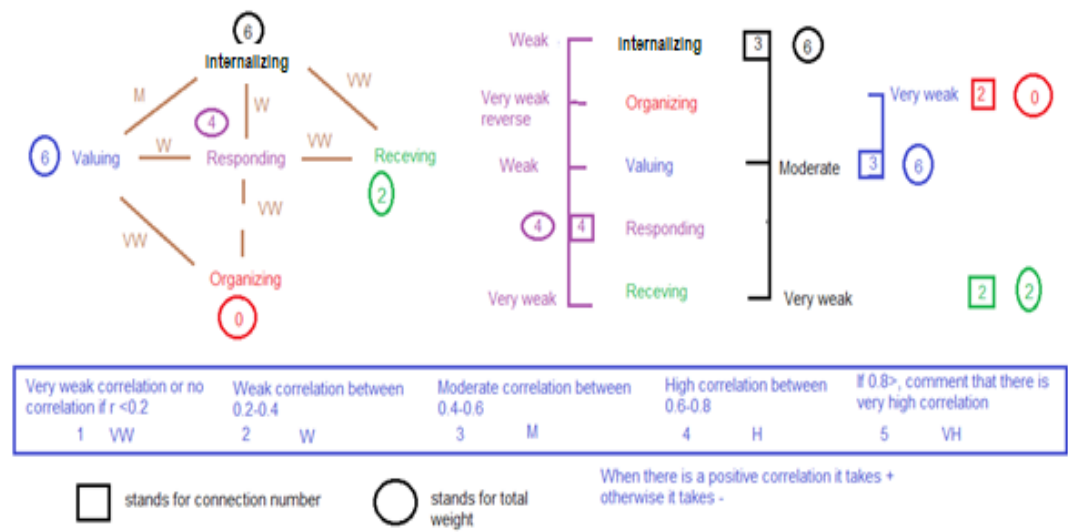

Figure 4: The schematization of the calculation of strength value of each sub-dimension and their connection graph 
Table 12: The neural network analysis of the importance level of each sub-dimensions

\begin{tabular}{|c|c|c|c|c|c|}
\hline & $\begin{array}{l}\text { Normalized Importance } \\
\text { for receiving }\end{array}$ & $\begin{array}{l}\text { Normalized Importance } \\
\text { for responding }\end{array}$ & $\begin{array}{l}\text { Normalized Importance } \\
\text { for valuing }\end{array}$ & $\begin{array}{l}\text { Normalized Importance } \\
\text { for organizing }\end{array}$ & $\begin{array}{l}\text { Independent Variable } \\
\text { Importance for } \\
\text { Characterizing }\end{array}$ \\
\hline Characterizing & $77,6 \%$ & $80,6 \%$ & $100,0 \%$ & $37,1 \%$ & - \\
\hline Organizing & $100,0 \%$ & $90,3 \%$ & $59,5 \%$ & - & $24,1 \%$ \\
\hline Valuing & $51,6 \%$ & $77,6 \%$ & - & $100,0 \%$ & $100,0 \%$ \\
\hline Responding & $76,7 \%$ & - & $65,0 \%$ & $90,3 \%$ & $77,2 \%$ \\
\hline Receving & - & $100,0 \%$ & $25,1 \%$ & $47,4 \%$ & $41,0 \%$ \\
\hline
\end{tabular}

The strength values can be found as below:

$$
S_{\text {receiving }}=\sum_{i=0, j=0, k=0}^{n} c_{i} \times p_{j} \times i_{k}=1 \times 1 \times 4+1 \times 1 \times 4=8
$$

$S_{\text {responding }}=\sum_{i=0, j=0, k=0}^{n} c_{i} \times p_{j} \times i_{k}=$

$$
1 * 2 * 5+1 *(-1) * 5+1 * 2 * 4+1 * 1 * 5=18
$$

$S_{\text {valuing }}=\sum_{i=0}^{n} c_{i} \times p_{i}=1 * 3 * 5+1 * 1 * 3+1 * 2 * 2=22$

$S_{\text {responding }}=\sum_{i=0, j=0, k=0}^{n} c_{i} \times p_{j} \times i_{k}=1 *-1 * 5+1 * 1 * 5=0$

$\mathrm{S}_{\text {characterizing }}=\sum_{i:{ }_{\mathrm{i}}^{n}}^{n} \times \mathrm{p}_{\mathrm{j}} \times \mathrm{i}_{\mathrm{k}}=1 * 3 * 5+1 * 2 * 4+1 * 1 * 2=25$

To the there we get strength values based on correlation and importance levels implying that something that might be important might not be correlated or vice versa. However, we should have a measure to understand what these numbers are. For example, is the strength value of responding as 18 is high or low? We can make this comparison in two ways. One is a relative comparison. We can say that the relative maximum is 25 by characterizing and the relative minimum is 0 by organizing and we divide this range into intervals as very high, very low, etc. However, such a strength comparison gives only us the idea of how much strength one particular dimension has concerning the other. If we want to compare our values in a more objective sense we should look at the range of the formula and find the absolute maximum and minimum values of it. As for equation 3, we have 5 dimensions for the affective domain. The maximum point that can get from correlation is +5 and the minimum value is -5 according to the categorization above. Similarly, the maximum value that can get from the importance level is 5 and the minimum value is 0 . Therefore, the absolute upper bound of our equation 3 is 125 $\left(5^{\star} 5+5^{\star} 5+5^{\star} 5+5^{\star} 5+5^{\star} 5\right)$ and the minimum lower bound is -125 . In there, negative strength values can be disregarded because it is meaningless to evaluate the negative strength values for concepts like affective domain. Hence, we can consider, the values in terms of absolute values. Therefore, our range should be between 0 and 125 . Just as done for importance and correlations levels we can calculate the significant value that is 125 in this case by dividing the strength value to the absolute upper bound of the strength value as follows:

Significance $=\frac{\text { strength value }}{\text { absolute upper bound of strength value }}=\frac{\text { strength value }}{125}$ Eqn 4

Therefore, if our strength value is 125 we get 1 and if it is 0 we get 0 . Just as significant values in correlation analysis our significance level should be between 0 and 1 and 1 implies the strongest significance and 0 is no significance. When we get the significance values, the receiving is $0,064(8 / 125)$, responding is
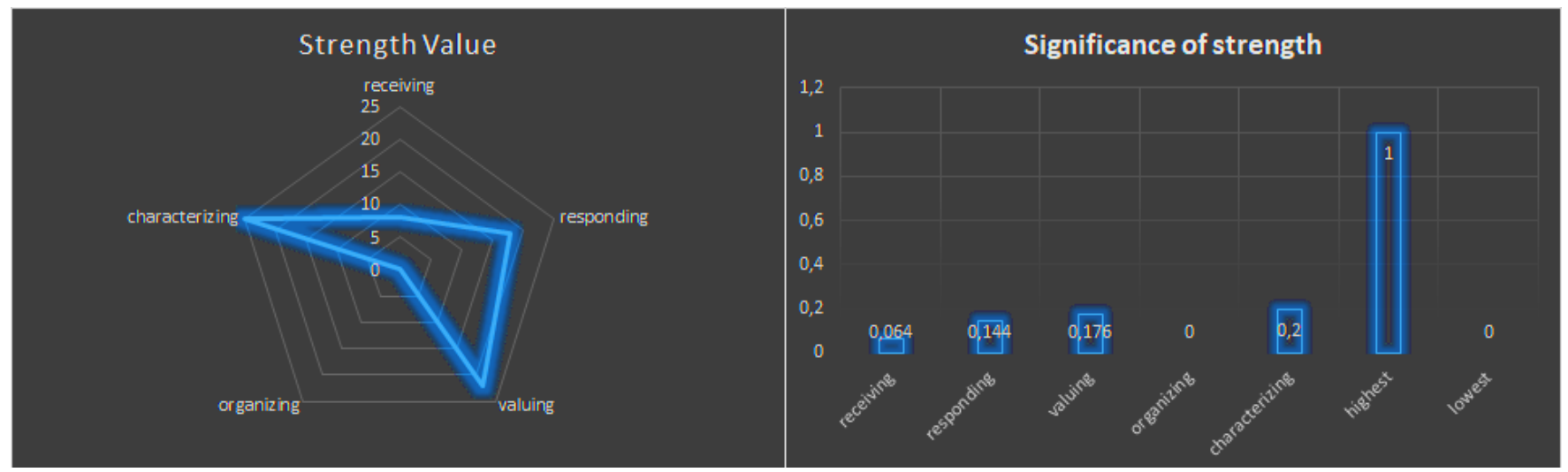

Figure 5: Strength and significance of strength 
$0,144(18 / 125)$, valuing is $0,176(22 / 125)$, organizing is $0(0 / 125)$ and characterizing is $0,2(25 / 125)$.

As can be seen, figure 5 characterizing has the highest strength value but it has a low value in terms of the significance level. For the other dimensions, we also find that these values are too weak according to equations 3 and 4 . It implies that affective domain values don't have so many and deep connections in the teacher candidates.

\subsection{The path and multilinear regression analysis for the sub-dimensions of the Environmental Problems Attitude of the students}

We can create a model based on the correlation constants and strength values of each sub-dimensions as given below in Figure 6.

The path diagram of the model shows that the model is very poor in terms of many variables as given in the table below. It should be noted that different models were also tried but they have similar features as well (Table 13).

Although the variables are not normally distributed according to the Kolmogorov-Smirnov test, skewness and kurtosis values of Characterizing, organizing, and valuing dimension are in the range between +1.5 and -1.5 so that linear regression analysis can be conducted between two variables while the skewness and kurtosis values of responding and receiving are not suitable (Tabachnick \& Fidell, 2013).

The regression model summary is given in Table 14. According to Table 14, the change in $29 \%$ of valuing can be explained by organizing and Characterizing sub-dimensions.

Table 15. shows the ANOVA results in which valuing is significantly predicted by organizing and Characterizing sub-dimensions.
Coefficients for the regression equation is given in Table 16. According to these coefficients, a regression equation can be given as follows:

Valuing $=(0,056$ organizing $)+(0,456$ Characterizing $)+3,230$

We create a second model based on the neural network analysis given in figure 7 .

Path diagram of the model shows that the model is very poor in terms of many features as given in the table below (Table 17).

\subsection{Qualitative data analysis}

When the sentiment analysis was done to the question of "What are your thoughts on the importance of foundations and associations in the formation of environmental understanding in the Ottoman Empire?" We get a neutral tone according to seoscout online sentiment analysis [1]. Actually, in this question, we don't want to get their information about the subject but their emotions regarding the concept (Table 18).

Kruskal Wallis Test results show that there are significant differences in terms of the mean rank values of the number of words the students express their feelings and their emotions regarding the formation of environmental understanding in the Ottoman Empire (Chi-Square=85,182, $\mathrm{df}=6$, Asymp. Sig.=,000). It is observed that they have the highest mean rank for slightly positive expressions and the lowest mean rank for very negative expressions (Table 19).

When the sentiment analysis was conducted to the question of " 2 -What are your thoughts on the importance of education in the development of environmental awareness in Turkey?" We get a neutral tone according to seoscout online sentiment analysis [1]. Actually, in this question, we don't want

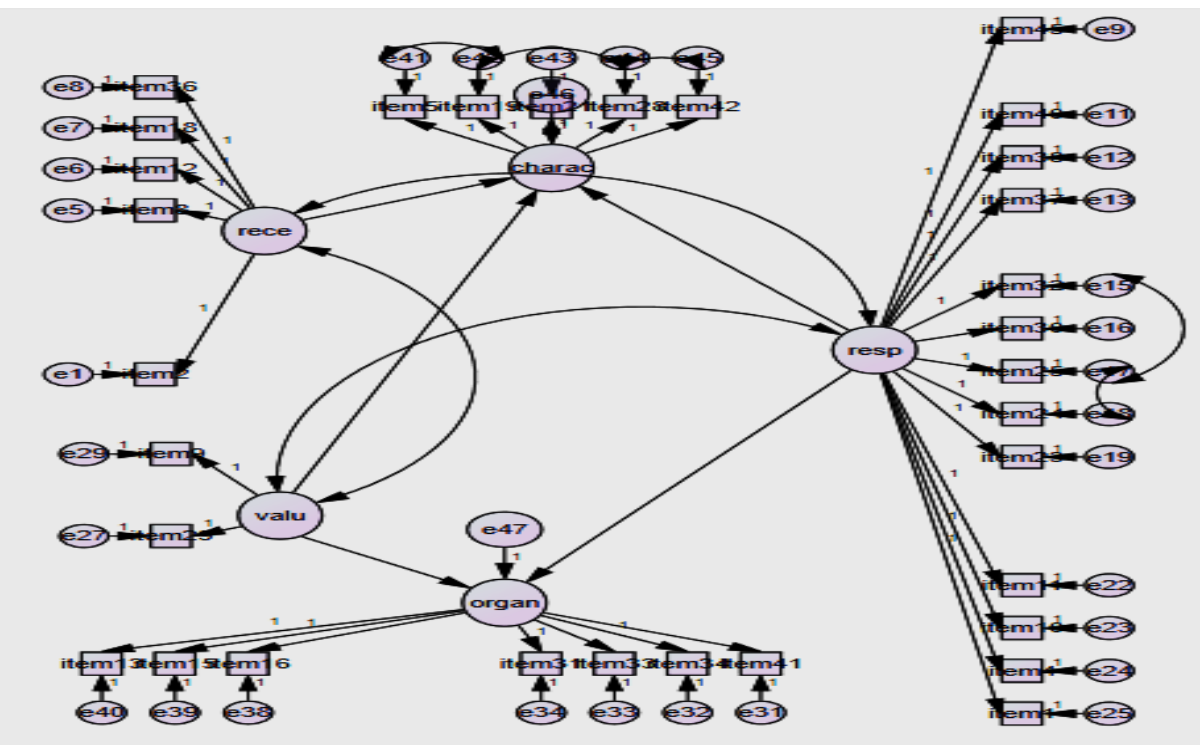

Figure 6: Path diagram of the model based on the correlation constants and strength values of each sub-dimensions 
Table 13: Path analysis results

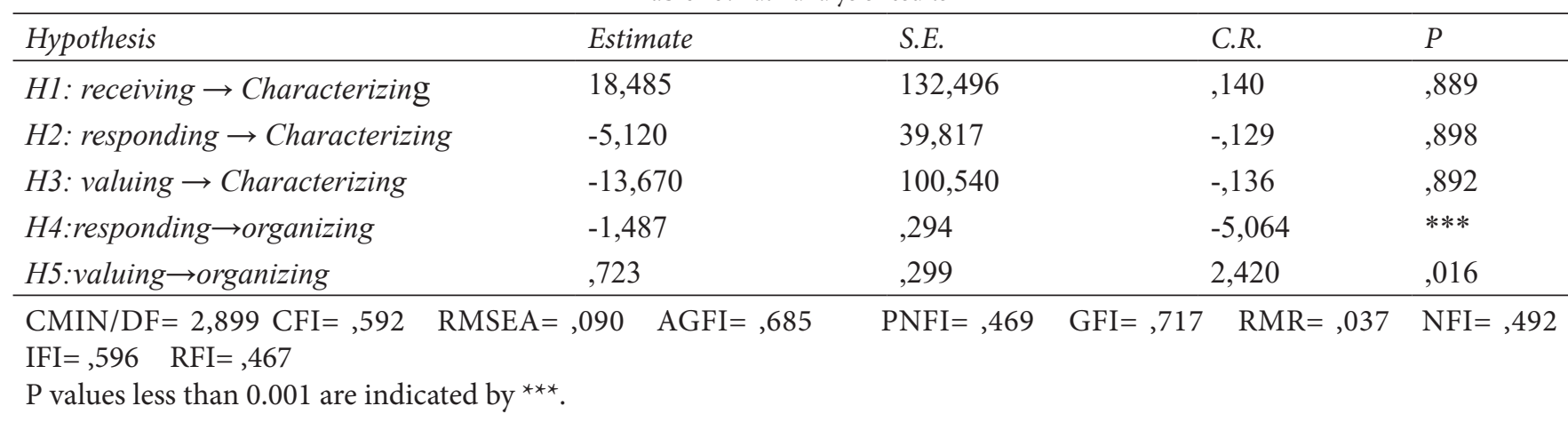

Table 14: Model summary of regression analysis for valuing sub-dimension

\begin{tabular}{lllll}
\hline \multicolumn{4}{c}{ Model Summary } \\
\hline Model & $R$ & $R$ Square & Adjusted R Square & Std. Error of the Estimate \\
\hline 1 &, $540 \mathrm{a}$ &, 291 & 1,30285 \\
\hline a. Predictors: (Constant), Organizing, Characterizing b: Dependent Variable: Valuing & &
\end{tabular}

Table 15: ANOVA Table for the Regression Analysis

\begin{tabular}{|c|c|c|c|c|c|c|}
\hline \multicolumn{7}{|c|}{ ANOVA } \\
\hline Model & & Sum of Squares & $D f$ & Mean Square & $F$ & Sig. \\
\hline \multirow[t]{3}{*}{1} & Regression & 162,535 & 2 & 81,267 & 47,877 & ,000b \\
\hline & Residual & 395,499 & 233 & 1,697 & & \\
\hline & Total & 558,034 & 235 & & & \\
\hline
\end{tabular}

a. Dependent Variable: Valuing

b. Predictors: (Constant), Organizing, Characterizing

Table 16: Coefficients for the Regression Equation

Coefficientsa

\begin{tabular}{|c|c|c|c|c|c|c|}
\hline \multirow{2}{*}{$\begin{array}{l}\text { Model } \\
\text { B }\end{array}$} & & \multicolumn{2}{|c|}{ Unstandardized Coefficients } & \multirow[t]{2}{*}{$\begin{array}{l}\text { Standardized } \\
\text { Coefficients }\end{array}$} & \multirow[b]{2}{*}{$\mathrm{T}$} & \multirow[b]{2}{*}{ Sig. } \\
\hline & & Std. Error & Beta & & & \\
\hline \multirow[t]{3}{*}{1} & (Constant) & 3,230 & ,753 & & 4,291 &, 000 \\
\hline & Characterizing & ,456 & ,049 &, 515 & 9,278 &, 000 \\
\hline & Organizing &, 056 &, 027 &, 117 & 2,109 & ,036 \\
\hline $\mathrm{R}=0,540$ & $\begin{array}{l}\mathrm{R} 2=0,291 \\
\mathrm{~F}=47,877 \\
\mathrm{p}=0,000\end{array}$ & & & & & \\
\hline
\end{tabular}

a. Dependent Variable: Valuing

b. Predictors: (Constant), Organizing, İnternalizing

Table 17: Path analysis results

\begin{tabular}{|c|c|c|c|c|}
\hline Hypothesis & Estimate & S.E. & C.R. & $P$ \\
\hline $\mathrm{H} 1$ : Characterizing $\rightarrow$ valuing & 1,128 &, 310 & 3,639 & $* * *$ \\
\hline $\mathrm{H} 2$ : valuing $\rightarrow$ organizing &,- 267 & ,095 & $-2,820$ & ,005 \\
\hline $\mathrm{H} 3$ : organizing $\rightarrow$ receiving & $-2,393$ & ,786 & $-3,044$ &, 002 \\
\hline H4:responding $\rightarrow$ receiving & 1,331 & , 103 & 12,949 & $* * *$ \\
\hline
\end{tabular}

$\mathrm{CMIN} / \mathrm{DF}=2,670 \mathrm{CFI}=, 535 \quad \mathrm{RMSEA}=, 084 \quad \mathrm{AGFI}=, 620 \quad \mathrm{PNFI}=, 420 \quad \mathrm{GFI}=, 680$

$\mathrm{RMR}=, 043 \quad \mathrm{NFI}=, 424 \quad \mathrm{IFI}=, 541 \quad \mathrm{RFI}=, 399$

$P$ values less than 0.001 are indicated by ${ }^{* * *}$. 


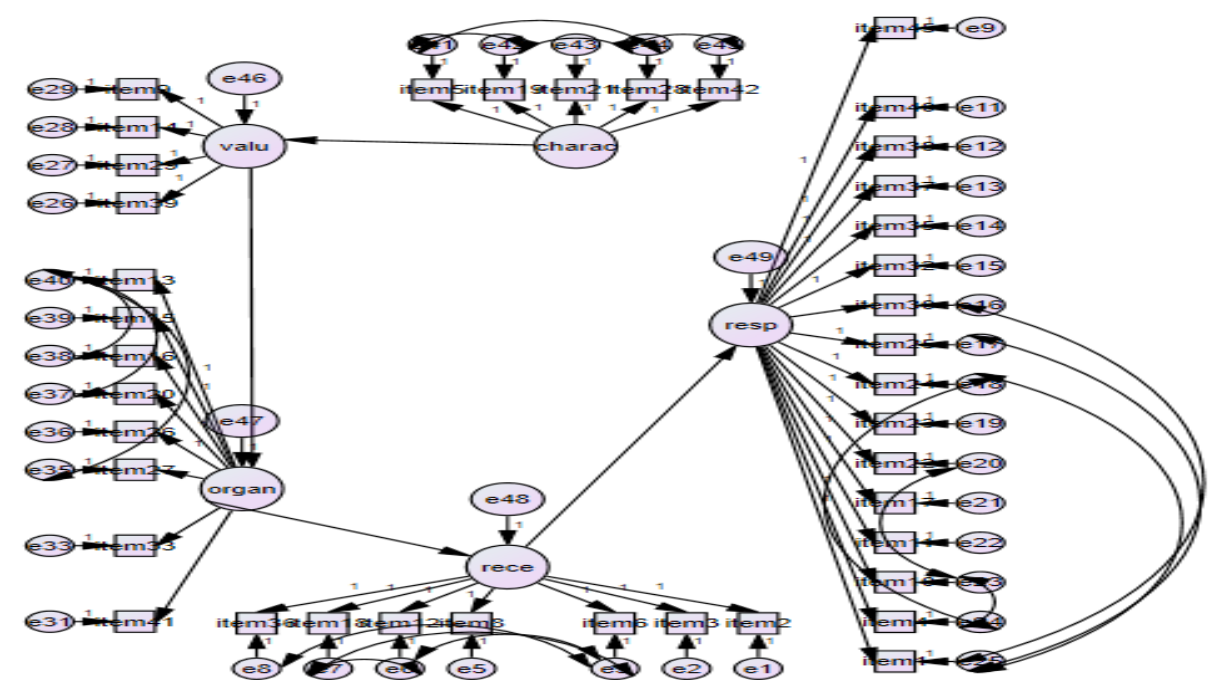

Figure 7: Path diagram of the model based on importance levels of neural network analysis of each sub-dimensions

Table 18: The frequency of sentiment analysis scores regarding the formation of environmental understanding in the Ottoman Empire

\begin{tabular}{llllll}
\hline \multicolumn{5}{c}{ Sentiment } \\
\cline { 2 - 6 } & & \multicolumn{5}{c}{ Cumulative Percent } \\
\hline Valid & Very slightly positive & 61 & Percent & Valid Percent & 20,3 \\
& Negative & 29 & 20,3 & 20,3 & 29,9 \\
& Neutral & 107 & 9,6 & 9,6 & 65,4 \\
& Slightly negative & 34 & 35,5 & 35,5 & 76,7 \\
& Positive & 53 & 11,3 & 11,3 & 94,4 \\
& Slightly positive & 15 & 17,6 & 5,0 & 99,3 \\
& Very negative & 2 & 5,0 &, 7 & 100,0 \\
\hline
\end{tabular}

to get their information about the subject, but their emotions regarding the concept show that they are neutral regarding the development of environmental awareness in the modern Turkish Republic (Table 20).

Kruskal Wallis Test results show that there are significant differences in terms of mean rank values of the number of words the students express their feelings and their emotions regarding the formation of environmental understanding in the Turkish Republic (Chi-Square=78,886, df=6, Asymp. Sig.=,000). It is observed that they have the highest mean rank for slightly positive expressions and the lowest mean rank for very negative expressions (Table 21).

When we compare the percentage of the words in terms of emotions given above the frequency tables, it seems that students used more words describing their feelings of very positive, negative, skepticism, positive expressions regarding the formation of environmental understanding in the Ottoman Empire, while they use more words describing their feelings in neutral and slightly positive expressions (Table 22).
We can see these values also in the graph as given below. It can be seen that only neutral and very negative expressions are in favor of expressions for the Turkish Republic period (Figure 8).

\section{Discussion}

When the mean values of the students' answers were investigated, it can be proposed that their level could be associated with responding level since they have the highest scores compared to others. Responding is the second level of the affective domain which is related to active participation in a particular subject and willingness to respond, or satisfaction in responding (motivation) is the main kind of affective behavior.

Mann-Whitney $U$ test results show that there is no significant difference for student's environmental problems attitude in terms of gender except for the responding dimension in favor of males. Güven (2017) found that the educational gender of pre-service science teachers was not statistically significant which is in parallel with this study. 


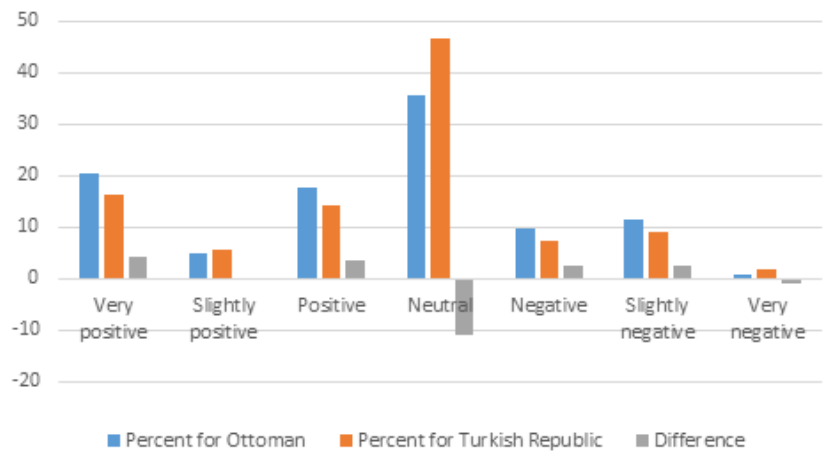

Figure 8. The percentage of the words in terms of emotion

Table 20: The frequency of sentiment analysis scores regarding the formation of environmental understanding in the Turkish Republic

\begin{tabular}{lllll}
\hline \multicolumn{5}{c}{ Sentiment 1 } \\
\hline & Frequency & Percent & $\begin{array}{l}\text { Valid } \\
\text { Percent }\end{array}$ & $\begin{array}{l}\text { Cumulative } \\
\text { Percent }\end{array}$ \\
\hline Very & & & & \\
positive & 57 & 16,1 & 16,1 & 16,1 \\
Negative & 26 & 7,3 & 7,3 & 23,4 \\
Neutral & 165 & 46,5 & 46,5 & 69,9 \\
$\begin{array}{l}\text { Slightly } \\
\text { negative }\end{array}$ & 32 & 9,0 & 9,0 & 78,9 \\
$\begin{array}{l}\text { Positive } \\
\text { Slightly }\end{array}$ & 50 & 14,1 & 14,1 & 93,0 \\
positive & 19 & 5,4 & 5,4 & 98,3 \\
Very & & 1,7 & 1,7 & 100,0 \\
negative & 6 & 1,7 & 100,0 & \\
Total & 355 & 100,0 & &
\end{tabular}

Table 22: The percentage of the words in terms of emotions

\begin{tabular}{llll}
\hline & Percent for & $\begin{array}{l}\text { Percent for } \\
\text { the Turkish } \\
\text { Republic }\end{array}$ & $\begin{array}{l}\text { Difference } \\
\text { between } \\
\text { Ottoman } \\
\text { and Turkish } \\
\text { Republic }\end{array}$ \\
Emotion & 20,3 & 16,1 & 4,2 \\
\hline Very positive & 9,6 & 7,3 & 2,3 \\
Negative & 35,5 & 46,5 & -11 \\
Neutral & 11,3 & 9 & 2,3 \\
Slightly negative & 17,6 & 14,1 & 3,5 \\
Positive & & & $-0,4$ \\
Slightly positive & 5 & 5,4 & -1 \\
Very negative & 0,7 & 1,7 & \\
\hline
\end{tabular}

There are also studies revealing that there is no significant difference between male and female teacher candidates in the dimensions of environmental knowledge, environmental
Table 19: Kruskal Wallis Test results for the mean rank values of the number of words in terms the emotions regarding the formation of environmental understanding in the Ottoman Empire

\begin{tabular}{llll}
\hline \multicolumn{3}{c}{ Ranks } \\
\hline \multirow{4}{*}{ Words } & Sentiment & $N$ & Mean Rank \\
& Very slightly positive & 61 & 119,15 \\
& Negative & 29 & 208,53 \\
& Neutral & 107 & 131,09 \\
& Slightly negative & 34 & 92,41 \\
& Positive & 53 & 215,52 \\
& Slightly positive & 15 & 228,43 \\
& Very negative & 2 & 59,00 \\
Total & 301 & \\
\hline
\end{tabular}

Table 21: Kruskal Wallis Test results for the mean rank values of the number of words in terms the emotions regarding the formation of environmental understanding in the Turkish Republic

\begin{tabular}{llll}
\hline \multicolumn{3}{c}{ Ranks } \\
\hline \multirow{2}{*}{ words1 } & sentiment1 & $N$ & Mean Rank \\
& Very positive & 57 & 113,23 \\
& Negative & 26 & 179,21 \\
& Neutral & 165 & 157,25 \\
& Slightly negative & 32 & 228,27 \\
& Positive & 50 & 250,87 \\
& Slightly positive & 19 & 273,47 \\
& Very negative & 6 & 181,00 \\
& Total & 355 & \\
\hline
\end{tabular}

attitude, or environmental behavior (Kahyaoğlu et al., 2008; Kışoğlu et al., 2016; Timur \& Yılmaz, 2011; Timur et al., 2013; 2013b). It seems that being male or female is not so important for the attitudes toward educational problems. Responding represents a student's more apparent action for his/her willingness to show his/her interest. An individual in this level, not only has an interest in the action but also freely contributes, takes initiatives, and is pleased with the opportunity to be involved (Savickiene, 2010). Therefore, we can conclude that male students more actively are engaged in environmental problems and communicates their interests in a specific way. Contrary to this finding, Uyar (2019), Kesicioğlu and Alisinanoğlu, (2009), Özpınar (2009), Tecer (2007), Şama (2003) and Erol (2005) found that female students are more interested in the environment than male students and tend to behave responsibly towards the environment. However, it should be noted that the population of these studies is different from the population of this study. For instance, Uyar's (2019) sample is from secondary school students, although Şama's (2003) sample and Erol's (2005) were from teacher candidates, one was done in 2003, 18 years ago from this study and the other was done from 16 years ago. Therefore, factors such 
as time, location as well as population characteristics might be effective regarding such variations so that we can make similar comments for the other demographic characteristics. There always be a debate of "Men Are from Mars, Women Are from Venus" in many subjects focused in the literature. Such a debate gains importance especially a concept like the affective domain since there are many biases and beliefs regarding the emotional character of men and women in many aspects. These debates, especially quantitative ones, never agree on how and why gender is effective for explaining particular behaviors, attitudes, or beliefs. In this study, we saw that gender is not an effective variable in most of the subdimensions of environmental problems attitudes. This can stem from not only the because of effects of other variables but also the heterogeneous character of the population in terms of many features. However, it should be emphasized that there might no significant difference in terms of gender because education, social life, or present technologies and mass media eliminates the effect of such a variable in different ways such as education, communication. Furthermore, since all the levels are interrelated to some extent, the evidence that there is only one sub-dimension showing significant difference implies the degree of the students' consistency in the affective domain because even upper levels have no significant difference but they have only significant difference second-lowest level. As implied by path analysis results mentioned following pages, they are probably at receiving level but they think their level is higher than actually is so that they give inconsistent answers according to the affective domain taxonomy of Bloom, et al. (1956) and they probably give higher scores based on this perception leading to surprising and incoherent results.

Kruskal Wallis Test shows that there is no significant difference for student's environmental problems attitude in terms of their grades and whether they like their departments or not, their location where they live. Güven et. al. (2012) and Güven (2017) found that the educational grades of the pre-service science teachers were not statistically significant which is in parallel with this study. However, Güven (2017) found that the longest-lived area was statistically significant on the behalf of pre-service science teachers who have grown up in the countryside. Therefore, according to our results, their responding level seems to be independent of those demographic variables. No variation across grades indicates that their education seems to be not effective in terms of elevating their level in the affective domain. No variation across in terms of whether they like their departments or not indicates that their affective attitudes toward their departments are not considered effective for their environmental problems attitude. Finally, no variation across locations indicates that their attitudes are not changing with the location since it might be possibly the result of the development of communication and media technologies.
The Kruskal Wallis test shows that there is no significant difference in students' environmental problems attitude in terms of graduation except for receiving dimension in favor of vocational high schools. It seems that there are no educational discrepancies among the schools in terms of awareness regarding environmental problems, but students in vocational high schools seem to be more likely to engage in dealing with environmental problems. No difference in the educational sense is important for such a general concept because it shows that education provides students with similar environmental awareness if the affective learning opportunities about this concept are high. However, if the effective learning for environmental education is poor, it can be regarded as a poor sign since environmental education is ineffectual for all types of schools.

Independent variable importance analysis shows that the most important factor for the demographic variables for students' environmental problems is gender and the second important factor is their attitude toward their departments. Therefore, we regard gender as an important factor compared to other demographic variables in the affective domain. It seems that the "Men Are from Mars, Women Are from Venus" debate outweighs other demographic variables in this respect. It should be noted that attitude toward their departments is also related to the affective domain, so it is no surprise to see it as a second important factor. It can be said that although gender doesn't significantly affect their attitudes, it should be regarded as an important factor comparing the other demographic variables.

Strength and significance of strength values show that characterizing has the highest strength value but in terms of significance levels, we can conclude that these values are too weak according to equations 3 and 4 . It implies that affective domain values don't have so many and deep connections in the teacher candidates. This possibly shows that students don't have coherent and logical Environmental Problems Attitudes. This can be seen in multilinear regression analysis showing that the change in $29 \%$ of value can be explained by organizing and Characterizing sub-dimensions. Such a change can be regarded as a small value, especially for two different factors, so that no causal and logical relationship can be inferred based on this. Such a situation is probably related to their educational background because no variation across grades indicates that their education seems to be not effective in terms of elevating their level in the affective domain. We can infer that communication tools are not effective in this respect because we found no variation across the location. The affective domain incorporates a sensation of feelings, perceptions of good or unpleasant well-being, stimulation of emotions linked to it, and excitement for action to approach the possibilities that people view as contributing to their viability, and escape the dangers that threaten it (Brett, Smith, Price, 
\& Huitt, 2003). Affective domain, in realizing values, is also necessary for this respect. In the entire field of the affective domain, internalization is an essential part of it to move to higher levels consistently. If a person internalizes some value, he or she begins to act by adopting and Characterizing it. In the affective domain, confusion, doubts, and inconsistencies are lost when one goes up to upper levels and the values learned at the upper points become the driving rules for one's existence (Gömleksiz and Kan, 2012; Akbaş, 2004: 42). Therefore, we can conclude that students' inconsistent and low-level environmental problems attitudes seem to show that they are actually at receiving/attending level, which is the lowest and most simple level of the affective domain (Savickiene, 2010). It seems that students are willing to take interest in environmental problems, but they do internalize them and take action.

When the sentiment analysis was conducted to the question of "What are your thoughts on the importance of foundations and associations in the formation of environmental understanding in the Ottoman Empire?", it is observed that the general mode of the expressions is neutral. When the sentiment analysis was done to the question of " 2 -What are your thoughts on the importance of education in the development of environmental awareness in Turkey?" we got a neutral tone also. Kruskal Wallis Test results show that there are significant differences in terms of the mean rank values of the number of words the students express their feelings and their emotions regarding the formation of environmental understanding in the Ottoman Empire and the Turkish Republic. It is observed that they have the highest mean rank for the slightly positive expressions and the lowest mean rank for the very negative expressions for both periods, indicating that they are slightly more prone to view both periods slightly positively. It seems that students have neither slightly positive nor negative emotions about the Turkish Republic compared to the Ottoman period. This can be explained by the fact that they consider these two different states in terms of information or their knowledge rather than their emotions.

\section{Conclusion}

Mann-Whitney $U$ test results show that there is no significant difference in students' environmental problems attitude in terms of gender except for the responding dimension in favor of males. The Kruskal Wallis test shows that there is no significant difference between students' environmental problems attitude in terms of their grades and whether they like their departments or not, their location where they live. The Kruskal Wallis test shows that there is no significant difference in students' environmental problems attitude in terms of graduation except for receiving dimension in favor of vocational high schools. Independent variable importance analysis shows that the most important factor for the demographic variables for students' environmental problems is gender and the second important factor is their attitude toward their departments.

In this study, we investigate the students' affective domain and attitudes and their perceptions about environmental problems by providing strength formula and significance formula. The strength formula consists of two variables. One is correlation constant and the other is importance value. Therefore, correlation values and normalized importance values are firstly investigated in this study. According to the results, that affective domain values shows that students don't have coherent and logical Environmental Problems Attitudes. In conclusion, students' inconsistent and low-level environmental issue views seem to indicate that they are really at the receiving/attending stage. Students seem to be willing to express an interest in environmental issues, but they do not seem to assimilate them or take action in response to them.

When we performed a sentiment analysis on the qualitative data, we discovered that the development of environmental understanding in the Ottoman Empire and the Turkish Republic was characterized by a neutral tone. Interestingly, they have the highest mean rank for the positive phrases and the lowest mean rank for the extremely negative expressions for both eras, suggesting that they are somewhat more likely to see both periods in a favorable light than the other participants. When comparing the Turkish Republic to the Ottoman Empire, it seems that students have neither good nor negative feelings about the Turkish Republic compared to the Ottoman period.

\section{SUGGESTION}

Strength formula can be used with different measurement tools. Especially, different measurement tools about affective domain can be useful to assess the effectiveness of strength formula. Different populations can also be used for the analysis based on strength formula. Sentiment analysis can be done with Sentimental Turkish Vocabulary to better understand student's emotions.

\section{Limitation}

One limitation of this study is that we use English translation of opinions rather than using direct Turkish versions because of lack of Turkish vocabulary for sentiment analysis. Secondly, strength formula can be expanded into more detailed form for more depth analysis.

\section{References}

Akbaş, O. (2004). Türk Milli Eğitim Sisteminin Duyuşsal Amaçlarının İlköğretim II. Kademedeki Gerçekleşme Derecesinin Değerlendirilmesi, Gazi Üniversitesi, Eğitim Bilimleri Enstitüsü, Yayımlanmamış Doktora Tezi, Ankara.

Bacanlı, H. (1999). Duyuşsal Davranış Eğitimi, Nobel Yayın Dağıtım: Ankara 
Bloom, B.S. (Ed.). Engelhart, M.D., Furst, E.J., Hill, W.H., Krathwohl, D.R. (1956). Taxonomy of Educational Objectives, Handbook I: The Cognitive Domain. New York: David McKay Co Inc.

Brett, A., Smith, M., Price, E., \& Huitt, W. (2003). Overview of the affective domain. Educational Psychology Interactive. Valdosta, GA: Valdosta State University. Retrieved [date], from http:// www.edpsycinteractive.org/brilstar/chapters/affectdev.pdf retrieved from 13.03.2021

Broekens, J., Kosters, W. A. ve Verbeek, F. J. (2007). Affect, anticipation, and adaptation: Affect-controlled selection of anticipatory simulation in artificial adaptive agents. Adaptive Behavior, 15(4), 397-422

Büyüköztürk, Ş., Kılıç Çakmak, E., Akgün, Ö.E., Karadeniz, Ş. ve Demirel, F. (2014). Bilimsel araştırma yöntemleri (17. Baskı). Ankara: Pegem Yayınları

Erol, G.H. (2005), Sınıf Öğretmenliği İkinci Sınıf Öğrencilerinin Çevre ve Çevre Sorunlarına Yönelik Tutumları, (Yüksek Lisans Tezi). Pamukkale Üniversitesi, Fen Bilimleri Enstitüsü, Denizli.

Gömleksiz, M. N. Kan, A. Ü. (2012). Affective Dimension İn Education And Affective Learning, Turkish Studies International Periodical For The Languages, Literature and History of Turkish or Turkic, 7(1), 1159-1177

Güven, İ., Yurdatapan, M., Benzer, E. ve Şahin, F. (2013). Fen bilgisi öğretmen adaylarının çevre sorunlarına yönelik tutumları ile sağlıklı yaşama yönelik tutumlarının değerlendirilmesi. Kastamonu Eğitim Dergisi, 21(4 (ÖS)), 1431-1448.

Güven, O. (2017). Fen bilgisi öğretmen adaylarının çevre problemlerine yönelik bilimsel düşünme alışkanlıklarının incelenmesi, Yayınlanmamış Yüksek Lisans Tezi, https://tez. yok.gov.tr/ retrieved from 13.03.2021

Kahyaoğlu, M., Daban, Ş. ve Yangın, S. (2008). İlköğretim öğretmen adaylarının çevreye yönelik tutumları. DÜ Ziya Gökalp Eğitim Fakültesi Dergisi, 11(1), 42-52.

Karasar, N. (2003). Bilimsel Araştırma Yöntemi, Ankara. Nobel Yayın Dağıtım

Kesicioğlu, O.S. ve Alisinanoğlu, F. (2009). 60-72 Aylık Çocukların Çevreye Karşı Tutumlarının Çeşitli Değişkenler Açısından İncelenmesi, Ahi Evran Üniversitesi Eğitim Fakültesi Dergisi, 10(3), 37-48.

Kışoğlu, M., Yıldırım, T., Salman, M. ve Sülün, A. (2016). İlkokul ve ortaokullarda çevre eğitimi verecek olan öğretmen adaylarında çevre sorunlarına yönelik davranışların araştırılması. Journal of Education Faculty, 18(1), 299-318.

Lopes, P. N., Brackett, M. A., Nezlek, J. B., Schütz, A., Sellin, I. ve Savery positivey, P. (2004). Emotional intelligence and social interaction. Personality and Social Psychology Bulletin, 30(8), 1018-1034.

Özdemir, E. (2015). Tarama Yöntemi. M.Metin (Ed.). Kuramdan Uygulamaya Eğitim Bilimlerinde Bilimsel Araştırma Yöntemleri (S. 77 - 97). Ankara: Pegem Akademi.

Özpınar, D. (2009). İlköğretim 4. ve 5. Sınıf Öğrencilerinin Çevre Sorunları Hakkındaki Görüşleri, Yayınlanmamış Yüksek Lisans Tezi, https://tez.yok.gov.tr/ retrieved from 13.03.2021

Savickiene, I. (2010). Conception of learning outcomes in the Bloom's taxonomy affective domain. Quality of Higher Education,7,37-59.

Şama, E. (2003). Öğretmen Adaylarının Çevre Sorunlarına Yönelik Tutumları. G.Ü. Gazi Eğitim Fakültesi Dergisi, 23(2), 99-110.

Tabachnick, B.G. Fidell, L.S. (2013). Using Multivariate Statistics (6th ed.) Boston: Pearson.

Tecer, S. (2007). Çevre İçin Eğitim: Balıkesir İli İlköğretim Öğrencilerinin Çevresel Tutum, Bilgi, Duyarlılık ve Aktif Katılım Düzeylerinin Belirlenmesi Üzerine Bir Çalışma, Yayınlanmamış Yüksek Lisans Tezi, https://tez.yok.gov.tr/ retrieved from 13.03.2021

Tekin, H. (2003). Eğitimde Ölçme ve Değerlendirme, (Gözden Geçirilmiş 16. Baskı), Yargı Yayınevi, Ankara

Timur, S. ve Yılmaz, M. (2011). Fen bilgisi öğretmen adaylarının çevre bilgi düzeylerinin belirlenmesi ve bazı değişkenlere göre incelenmesi. Gazi Üniversitesi Gazi Eğitim Fakültesi Dergisi, 31(1), 303-320.

Timur, S., Yılmaz, Ş. and Timur, B. (2013a). İlköğretim öğretmen adaylarının çevreye yönelik tutumlarının belirlenmesi ve farklı değişkenlere göre incelenmesi. Ahi Evran Üniversitesi Kırşehir Eğitim Fakültesi Dergisi, 14(2), 191-203.

Timur, S., Yılmaz, Ş. and Timur, B. (2013b). Öğretmen adaylarının çevreye yönelik davranışlarının incelenmesi. Yüzüncü Yıl Üniversitesi Eğitim Fakültesi Dergisi, 10(1), 169-189.

Uyar, S. N. (2009). Ortaokul öğrencilerinin çevre ve çevre problemlerine yönelik görüşlerinin farklı değişkenler açısından araştırılması, Yayınlanmamış Yüksek Lisans Tezi, https://tez. yok.gov.tr/ retrieved from 13.03.2021 